\title{
Perancangan Conveyor Mini untuk Pemilahan Buah Berdasarkan Ukuran yang Dikendalikan oleh Mikrokontroller Atmega16
}

\author{
Partaonan Harahap ${ }^{1}$, Benny Oktrialdi ${ }^{2}$, Cholish $^{1}$ \\ ${ }^{1}$ Program Studi Teknik Elektro Fakultas Teknik UMSU \\ ${ }^{2}$ Program Magister Teknik Elektro USU \\ Jl. Kapten Muchtar Basri,BA No. 03 Medan Telp. (061) 6622400 ex. 12 Kode pos $20238^{1}$ \\ Jl. Almamater, Medan Baru, Kota Medan Kode pos $20155^{2}$ \\ Email : partaonanharahap@umsu.ac.id ${ }^{1}$ \\ Email :bennyoktrialdiasman@gmail.com²
}

\begin{abstract}
Abstrak - Berkembang dan bervariasi, untuk memenuhi kebutuhan tersebut industri membutuhkan suatu alat yang dapat mengontrol dan mengendalikan proses permesinan secara otomatis sehingga mempermudah dan menghemat tenaga manusia. sebagian besar industri menerapkan sistem control menggunakan Mikrokontroller sebagai alat kontrol kerja produksi, seperti alat conveyor untuk pemilahan buah berdasarkan ukuran yang dikendalikan oleh Mikrokontroller ATMEGA16, dengan menggunakan sensor ultrasonic sebagai pengukur ukuran objek dan kombinasi photodioda dan motor servo dapat mendeteksi keberadaan objek lalu dapat mensortirnya. Perancangan conveyor pada penelitian ini menggunakan jenis Belt Conveyor dengan komponen utama roller dari bahan pvc, kerangka dari bahan akrelit, sabuk (Belt) dari bahan lakban, motor dc sebagai penggerak sabuk juga roda gigi (pulley) dan Terdapat 3 buah motor servo yang difungsikan untuk memilah buah jeruk berdasarkan ukuran kecil, sedang, dan besar. Perancangan conveyor yang dilengkapi pemilah benda ini dapat dibuat dengan menggunakan ATMEGA 16 sebagai kontrolernya. Sensor ultrasonic HCSR04 berfungsi dengan baik untuk mengukur ukuran objek, dan kombinasi photodioda dan motor servo dapat mendeteksi keberadaan objek lalu dapat memilahnya. Kemudian data dicacah oleh mikrokontroller dan ditampilkan pada layar LCD.
\end{abstract}

Kata kunci: Mikrokontroler ATMEGA16, Conveyor, sensor ultrasonic, photodioda, motor servo, CodeVision AVR

\section{Pendahuluan}

Berkembangnya teknologi yang semakin canggih dan modern seiring dengan kebutuhan manusia yang bervariatif kita dapat membuat sesuatu yang manual menjadi otomatis, sehingga akan mempermudah atau meringankan setiap pekerjaan. Dengan hal tersebut kita membutuhkan suatu alat berbasis mikrokontroler yang dapat diisi perintah program yang sesuai dengan kebutuhan berdasarkan nilai masukan (input) dan memprosesnya kemudian mengeluarkan hasil keluaran (output) berdasarkan perintah program yang telah tersimpan dalam memori IC[1].

Dari permasalahan tersebut maka peneliti ingin membuat sesuatu simulasi conveyor otomatis berbasis mikrokontroller yang dilengkapi dengan sensor ultrasonic sebagai pengukur benda berdasarkan ukuran, sehingga conveyor tersebut lebih efisien karena dapat mendistribusikan barang sekaligus memilahnya berdasarkan ukuran dan bila tidak sesuai dengan ukuran yang diinginkan maka conveyor akan meneruskan yang rusak [2][3].
Conveyor ini dilengkapi dengan 3 buah servo yang digunakan untuk mendorong barang yang dikelompokkan sesuai dengan ukurannya, sensor ultrasonic sebagai pengukur ukuran benda dan motor de sebagai penggerak belt conveyor [4]. Dengan adanya conveyor ini maka diharapkan dapat memecahkan masalah sekaligus mempermudah pengguna conveyor pada umumnya.

\section{Dasar Teori}

Mikrokontroler adalah sebuah chip yang berfungsi sebagai pengontrol rangkaian elektronik dan umumnya dapat menyimpan program di dalamnya. Ada perbedaan penting antara mikroprosessor dan mikrokontroler. Mikroprosesor merupakan CPU (Central Processing Unit) tanpa memori dan I/O pendukung sebuah computer, sedangkan mikrokontroler umumnya terdiri dari CPU, memori, I/O tertentu dan unit pendukung seperti Analog-to-Digital Converter $(A D C)$ yang sudah terintregasi di dalamnya. Kelebihan utama mikrokontroler ialah tersedianya RAM dan peralatan I/O pendukung sehingga ukuran board 
mikrokontroler menjadi sangat ringkas. Pada Mikrokontroler perbandingan ROM dan RAM nya yang besar, artinya program kontrol disimpan dalam ROM (bisa Masked ROM atau Flash PEROM) yang ukurannya relatif lebih besar, sedangkan RAM digunakan sebagai tempat penyimpan sementara, termasuk register-register yang digunakan pada mikrokontroler yang bersangkutan.

Mikrokontroler sekarang ini sudah banyak dapat kita temui dalam berbagai peralatan elektronik, misalnya peralatan yang terdapat di rumah, seperti telepon digital, microwave oven, televisi, dan masih banyak lagi. Mikrokontroler juga dapat kita gunakan untuk berbagai aplikasi misalnya untuk pengendalian suatu alat, otomasi dalam industri dan lain-lain. Keuntungan menggunakan mikrokontroler adalah harganya murah, dapat diprogram berulang kali, dan dapat diprogram sesuai dengan keinginan kita.

Didalam pembuatan Tugas Akhir ini penulis memilih mikrokontroler AVR ATMEGA 16 sebagai prosessor dari alat yang akan dibuat. AVR merupakan seri mikrokontroler CMOS 8 bit buatan Atmel, berbasis arsitektur RISC (Reduced Instruction Set Computer). Atmel merupakan salah satu vendor yang bergerak dibidang mikroelektronika, telah mengembangkan AVR (Alf and Vegard's Risc processor) sekitar tahun 1997. Pada dasarnya yang membedakan masing-masing kelas adalah memori, peripheral, dan fiturnya Seperti mikroprosesor pada umumnya, secara internal mikrokontroler ATMega16 terdiri atas unit-unit fungsionalnya Arithmetic and Logical Unit (ALU), himpunan register kerja, register dan dekoder instruksi, dan pewaktu beserta komponen kendali lainnya. Berbeda dengan mikroprosesor, mikrokontroler menyediakan memori dalam serpih yang sama dengen prosesornya (in chip).

Mikrokontroler ini menggunakan arsitektur Harvard yang memisahkan memori program dari memori data, baik bus alamat maupun bus data, sehingga pengaksesan program dan data dapat dilakukan secara bersamaan (concurrent).

Berikut Penjelasan mengenai konfigurasi Pin pada ATMEGA 16 :

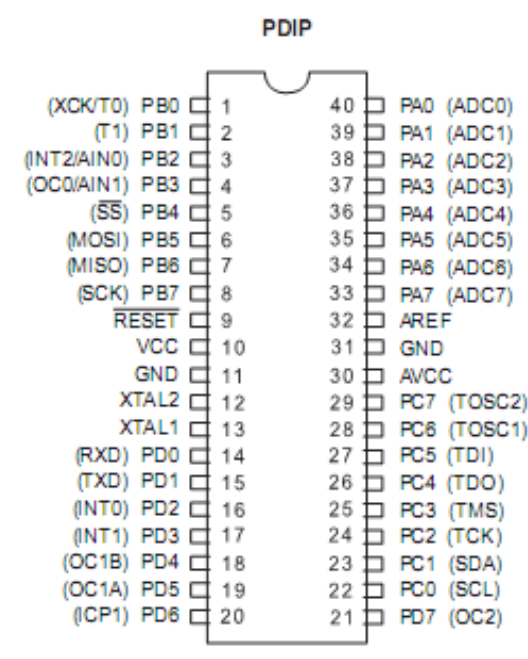

Gambar 1. Arsitektur ATMEGA16
Konfigurasi pena (pin) mikrokontroler Atmega16 dengan kemasan 40-pin dapat dilihat pada gambar diatas. Dari gambar tersebut dapat terlihat ATMega16 memiliki 8 pin untuk masing-masing Gerbang A (Port A), Gerbang B (Port B), Gerbang C (Port C), dan Gerbang D (Port D).

Secara garis besar Arsitektur ATMEGA 16 dapat dilihat pada Gambar 1.

1. Arsitektur RISC dengan throughput mencapai 16 MIPS pada frekuensi 16Mhz.

2. Memiliki kapasitas Flash memori 16Kbyte, EEPROM 512 Byte, dan SRAM 1Kbyte

3. Saluran I/O 32 buah, yaitu Port A, Port B, Port C, dan Port D.

4. CPU yang terdiri dari 32 buah register.

5. User interupsi internal dan eksternal

6. Port antarmuka SPI dan Port USART sebagai komunikasi serial.

7. Fitur Peripheral

a. Dua buah 8-bit timer/counter dengan prescaler terpisah dan mode compare

b. Satu buah 16-bit timer/counter dengan prescaler terpisah, mode compare, dan mode capture

c. Real time counter dengan osilator tersendiri

d. Empat kanal PWM dan Antarmuka komparator analog

e. 8 kanal, 10 bit ADC

f. Byte-oriented Two-wire Serial Interface

g. Watchdog timer dengan osilator internal

Conveyor adalah salah satu jenis alat pengangkut atau pemindah yang berfungsi untuk mengangkut atau memindahkan bahan-bahan industri yang berbentuk padat, terdiri dari ban berbentuk bulat menyerupai sabuk (Belt) yang diputar oleh motor. conveyor memiliki banyak jenis dibuat sesuai dengan kebutuhan industri seperti Belt Conveyor, Chain Conveyor, Screw Conveyor dapat dilihat pada Gambar 2.

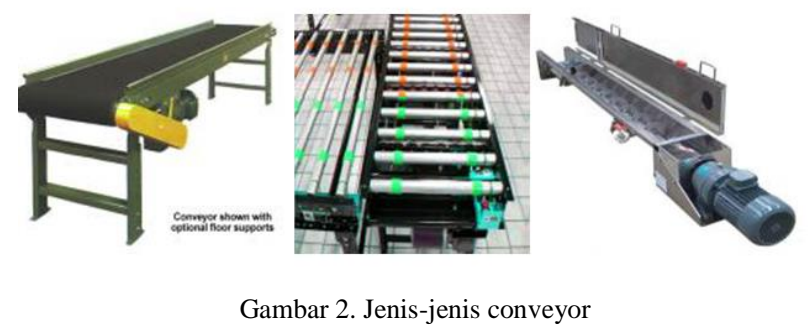

Dari banyak jenis conveyor maka dipilihlah conveyor Sabuk (Belt Conveyor) karena lebih mudah dibuat dan lebih hemat. Komponen utama dari conveyor Sabuk ini adalah : Roller, Sabuk (Belt), Rangka, Motor DC, Roda Gigi/Pulley.

Motor Driver berfungsi mengendalikan dan mengatur kecepatan putaran motor DC atau pun motor stepper karena membutuhkan arus yang cukup besar. Pada IC L298N, terdapat output 4 jalur yang dapat mengendalikan 1 atau 2 buah motor DC atau motor Stepper. Untuk motor DC cukup berikan logika high atau low disalah satu pin dari 2 pin yang digunakan oleh tiap motor, dimana logika high atau low menentukan arah putaran motor DC. Driver motor L298N dapat dilihat pada Gambar 3. 


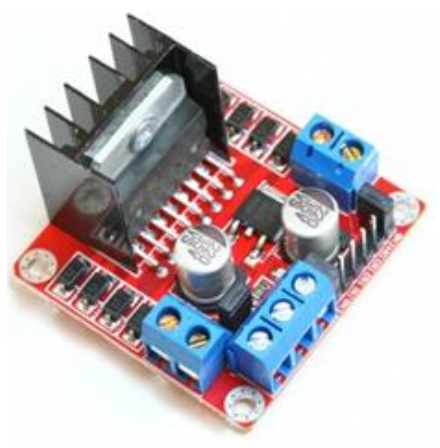

Gambar 3. driver motor L298N

HC-SR04 merupakan sensor ultrasonik yang dapat digunakan untuk mengukur jarak antara penghalang dan sensor HC-SR04 memiliki 2 komponen utama sebagai penyusunnya yaitu ultrasonic transmitter (trigger) dan ultrasonic receiver (echo). Fungsi dari ultrasonic transmitter adalah memancarkan gelombang ultrasonik dengan frekuensi $40 \mathrm{KHz}$ kemudian ultrasonic receiver menangkap hasil pantulan gelombang ultrasonik yang mengenai suatu objek.

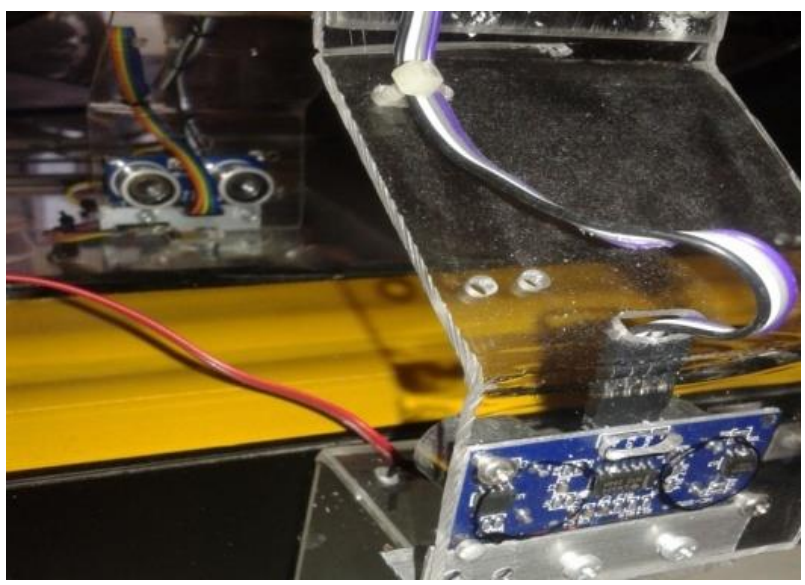

Gambar 4. Rangkaian Sensor Ultrasonic HC-SR04

\section{Metodologi Penelitian}

Langkah dalam perancangan ini terbagi dalam 2 bagian utama yaitu bagian perancangan elektronik meliputi semua tahap yang berhubungan dengan rangkaian misalnya perancangan rangkaian, pemilihan komponen, pencetakan dan pembuatan layout dan pencetakan di papan PCB (Printed Circuit Board), pemasangan komponen di PCB serta pengujian alat. Semua langkah- langkah tersebut dikerjakan secara teratur agar diperoleh hasil yang maksimal.

Penelitian dilaksanakan di Labolatorium kampus III Universitas Muhammadiyah Sumatera Utara, jalan Kapten Mukhtar Basri No.3 Glugur Darat II Medan. Peralatan penunjang yang digunakan untuk membuat alat conveyor untuk pemilahan buah jeruk berdasarkan ukuran ini adalah Multimeter sebagai peralatan utama pengukur dan pengetesan komponen yang mengacu pada besaran hambatan, Arus, dan Teganagan.

\section{A. Bahan-Bahan Penelitian}

Bahan-bahan yang digunakan untuk pembuatan alat ini yaitu :

1. laptop acer tipe Aspire V5-132, CPU intel(R) Celeron(R) processor 1019Y (1.0GHz, 2MB L3 cache) Memory 2 GB DDR3 L Memory , Operating System Windows 7 Ultimate.

2. Smartphone merk samsung berfungsi pengambil data dari internet dan pengambil foto alat ukur digital.

3. ATMEGA16 digunakan untuk mengontrol rangkaian keseluruhan.

4. Power supply yang terdiri dari transformator stepdown( 220 18 VAC ), penyearah dan filter( 4 dioda dan 2 capasitor), Converter DC-DC boost ( 18 24 VDC ), Converter DC-DC buck and boost ( 24 5 VDC ).

5. 3 buah sensor ultrasonic memancarkan gelombang dari Transmitter terhadap objek yang akan diukur, lalu pantulan gelombang dari objek akan dikirimkan ke Reiciver.

6. LCD 20x4 digunakan untuk menampilkan data berupa tulisan saat menerima perintah dari user.

7. 3 buah motor servo futaba S3003 dengan torsi $3.2 \mathrm{~kg} / \mathrm{cm}$.

8. Motor DC 24 VDC.

9. 3 buah sensor photodioda sebagai receiver dan LED infrared sebagai transmitter.

10. Timah sebagai bahan yang akan menghubungkan kaki komponen dengan jalur tembaga.

11. Kabel Jamper yang akan digunakan untuk menghubungkan jalur rangkaian yang terpisah.

12. Papan PCB dan akralit sebagai dudukan komponen.

13. Baut dan ring berbagai ukuran

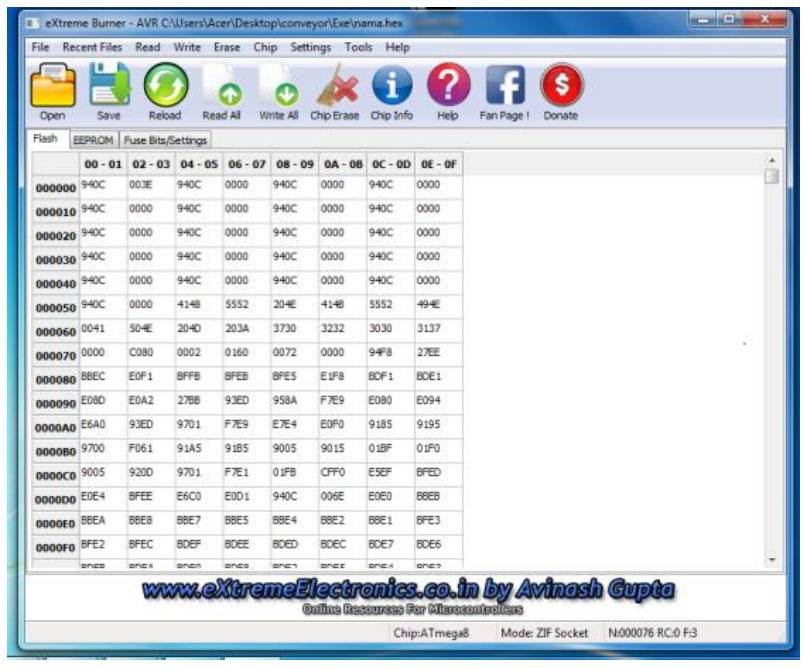

Gambar 5. Tampilan aplikasi eXtreme Burner

Pada flowchart yang telah dibuat berisi tentang informasi tentang alur kerja sistem alat yang dirancang mulai dari start awal sampai dengan hasil akhir. 


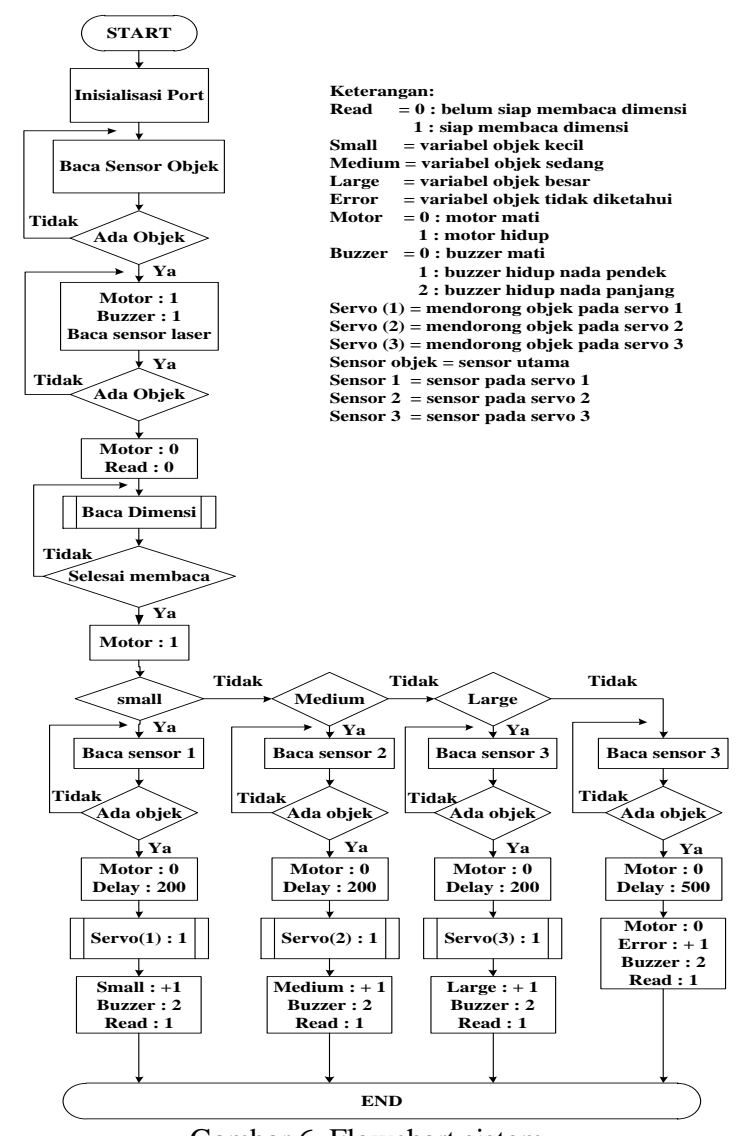

Gambar 6. Flowchart sistem

Model conveyor sebagai berikut: Belt conveyor: Panjang: $80 \mathrm{~cm}$, Lebar: $10 \mathrm{~cm}$; Roll conveyor: Diameter 5 cm.Pada penelitian ini digunakan motor DC $12 \mathrm{~V}$, motor servo futaba S3003, photodioda, LED, sensor ultrasonic, dll. Rancangan model conveyor dapat diliat pada Gambar 5.

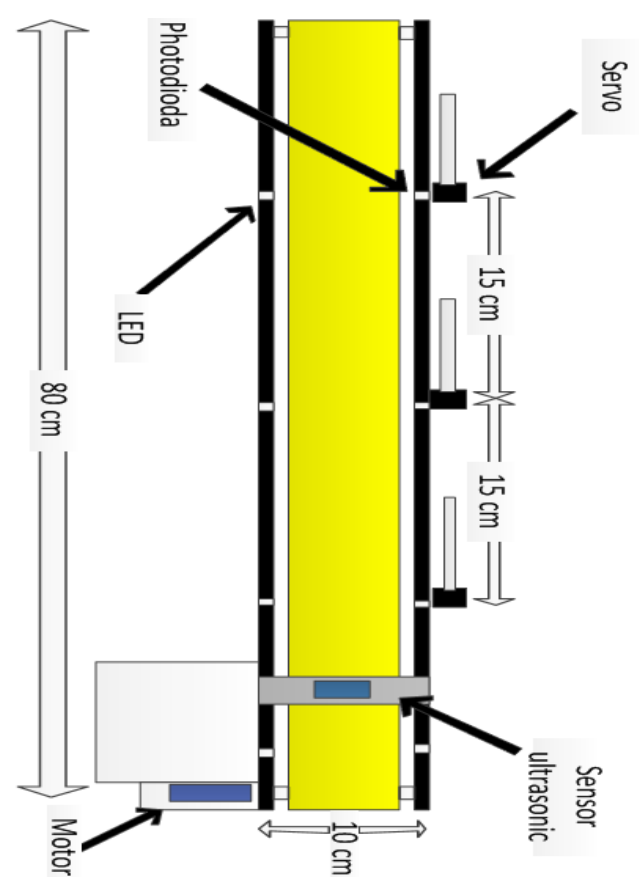

Gambar 7. Rancangan model conveyor

\section{Temuan dan Pembahasan}

Pengujian alat secara keseluruhan ini merupakan gabungan dari pengujian-pengujian tiap bagian input dan output yang telah dilakukan sebelumnya. Peralatan yang dibutuhkan untuk melakukan pengujian ini yaitu :

1. Minimum Sistem Arduino Uno R3.

2. Kabel data ATMEGA 16.

3. Laptop.

4. Modul Driver Motor.

5. Rangkaian Servo.

6. Rangkaian sensor Ultrasonic.

7. Rangkaian LCD.

8. Rangkaian Photodioda.

9. Software Code Vision AVR dan eXtreme Burner $A V R$.

Blok diagram pengujian Alat secara Keseluruhan seperti ditunjukkan pada Gambar 4.16 berikut ini :

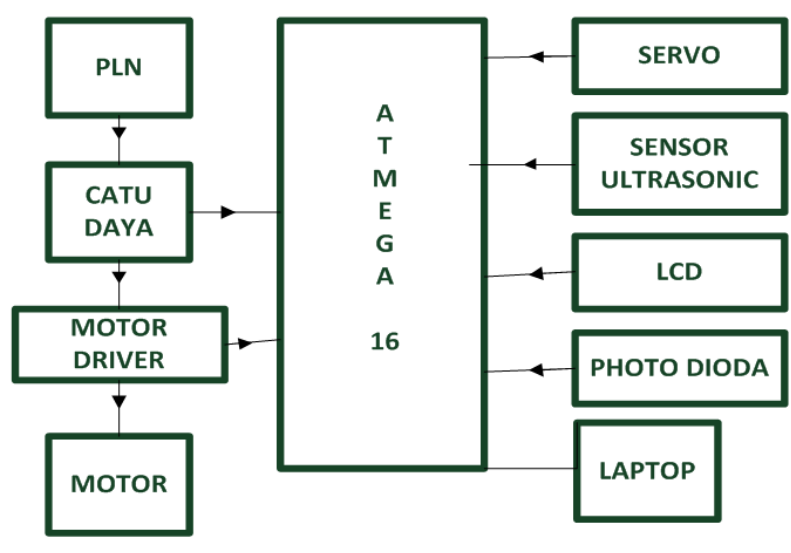

Gambar 8. Blok Diagram Pengujian Rangkaian Keseluruhan

Langkah-langkah melakukan pengujian Alat secara Keseluruhan :

1. Buka aplikasi Code Vision AVR.

2. Selanjutnya akan muncul tampilan awal Code Wizard AVR untuk memilih chip mikrokontroller mana yang digunakan dan pengaturan lainnya yang diperlukan seperti pada langkah sebelumnya.

3. Selanjutnya setelah selesai dengan segala pengaturan maka file di-save dalam berbagai type untuk keperluan membuat listing program dan compiler pada aplikasi extreme burner.

4. Klik Compile the project

5. Kemudian akan muncul kotak dialog untuk melihat apakah ada kesalahan dalam membuat listing program yang baru dibuat dapat dilihat pada Gambar 9. dibawah ini. 


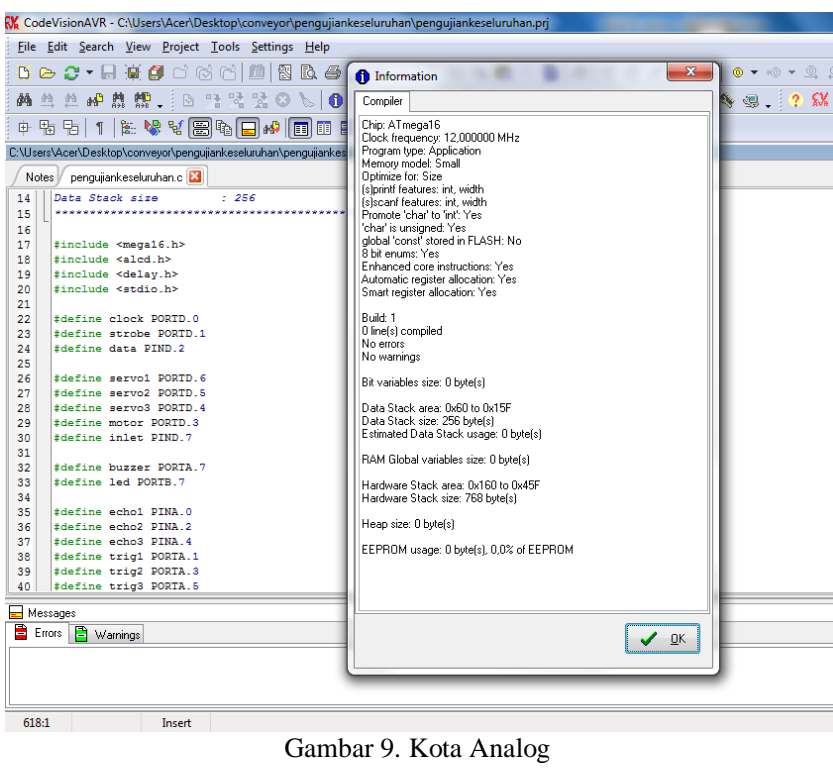

6. Selanjutnya buka aplikasi eXtreme Burner.

7. Selanjutnya klik $O P E N$, lalu buka file projek yang sebelumnya telah di simpan.

8. Setelah file projek dibuka maka akan diliat program berubah menjadi bilangan biner seperti sebelumnya.

9. Selanjutnya klik write all untuk men-download program ke mikrokontroller ATMEGA 16,

Selanjutnya program yang dibuat yaitu memanggil sub program yang telah dibahas sebelumnya, tindakan yang dilakukan pada program ini yaitu bila ada objek maka belt conveyor akan melaju membawa objek untuk menentukan hasil pengukuran berdasarkan ukuran yang diinginkan lalu mengirimkan informasi tersebut kepada photodioda pada servo yang telah ditentukan untuk mensortir objek tersebut.

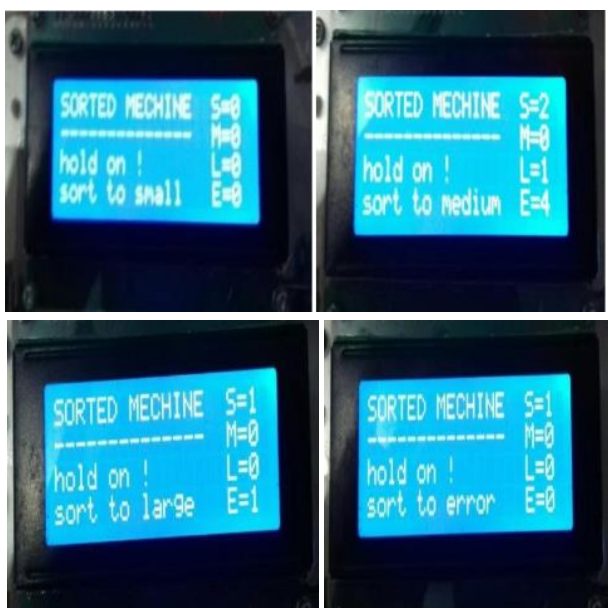

Gambar 10.Tampilan LCD Hasil Pengujian

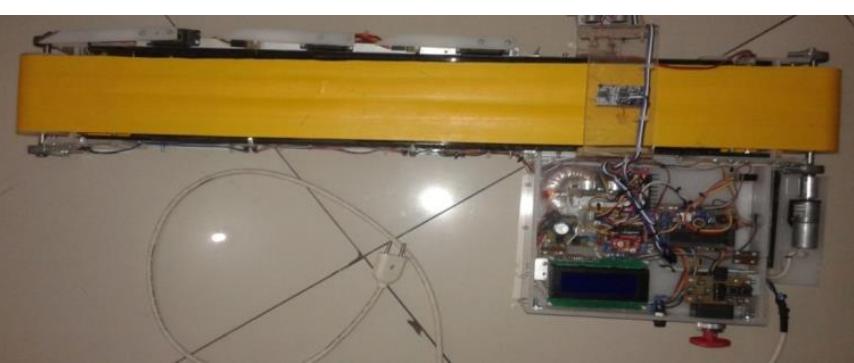

Gambar 11.Tampilan Alat Secara Keseluruhan

Tabel 1. Data hasil pengujian keseluruhan pengukuran benda dan waktu tempuh benda

\begin{tabular}{|c|c|c|c|c|}
\hline No. & Kategori Benda & \multicolumn{2}{|c|}{ Ukuran Benda } & Waktu tempuh \\
benda
\end{tabular}

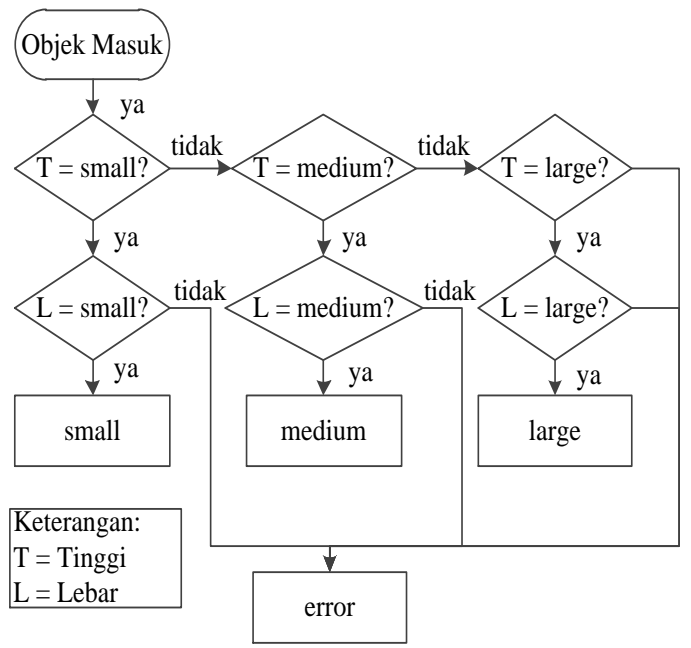

Gambar 12. Flowchart Pembacaan Objek

\section{Simpulan}

Berdasarkan Setelah dilakukan proses perencanaan, pembuatan dan pengujian alat maka dapat di simpulkan beberapa hal serta sekaligus menjawab rumusan masalah, maka dapat di ambil kesimpulan sebagai berikut :

1. Perancangan conveyor pada penelitian ini menggunakan jenis Belt Conveyor dengan komponen utama roller dari bahan $p v c$, kerangka dari bahan akrelit, sabuk (Belt) dari bahan lakban, motor dc sebagai penggerak sabuk juga roda gigi (pulley) dan Terdapat 3 buah motor servo yang difungsikan untuk memilah buah jeruk berdasarkan ukuran kecil, sedang, dan besar.

2. Perancangan conveyor yang dilengkapi pemilah benda ini dapat dibuat dengan menggunakan ATMEGA 16 sebagai kontrolernya. Sensor ultrasonic HC-SR04 berfungsi dengan baik untuk mengukur ukuran objek, dan kombinasi photodioda dan motor servo dapat mendeteksi keberadaan objek lalu dapat memilahnya. 
Kemudian data dicacah oleh mikrokontroller dan ditampilkan pada layar LCD.

3. Untuk membuat listing program pada mikrokontroller ATMEGA 16 maka digunakan software CodeVision AVR dan software eXtreme Burner AVR sebagai downloader ke mikrokontroller.

\section{Kepustakaan}

[1] Andrianto Heri.2015." Pemrograman Mikrokontrole AVR Atmegal6 Menggunakan Bahasa C (Code Vision AVR)'.Penerbit Informatika.

[2] Bernanda Noprana, dkk Jurnal. 2013 "Perancangan mesin Pemindah Barang Berdasarkan Warna Dengan Loading System ". Palembang.
[3] Debit Zein Ariandana.. Jurnal. 2015. “ Rancang Bangun Konveyor Untuk Sistem Sortir Berdasarkan Berat Barang”. Surabaya.

[4] Emir Nasrullah, dkk. Jurnal. 2012." Model Sistem Kontrol Pemilahan Produk Berbentuk Kotak”. Bandar Lampung.

[5] Kadir Abdul.2015."Panduan Mempelajari Aneka Proyek Berbasis Mikrokontroler".'Yogyakarta: Penerbit Andi.

[6] M. Hendri. Jurnal. 2014. "Miniatur Conveyor Otomatis Berbasis Mikrokontroler". Jambi.

[7] Setiawan Afrie.2015." 20 Aplikasi Mikrokontroller ATMega 8535 \& ATMega 16 Menggunakan Bascom-AVR".Yogyakarta: Penerbit Andi.

[8] Ujang Sonjaya. Jurnal. 2016.“ Rancang Bangun Sistem Kontrol Konveyor Penghitung Barang Menggunakan PLC (Programmable Logic Controller) OMRON tipe CPM1A 20 CDR". 